\title{
In vivo screening and evaluation of four herbs against MRSA infections
}

\author{
Najma Arshad ${ }^{1 *}$, Arifa Mehreen ${ }^{1}$, Iram Liaqat ${ }^{2}$, Muhammad Arshad ${ }^{3}$ and Humera Afrasiab ${ }^{4}$
}

\begin{abstract}
Background: Recently, we reported high in vitro antibacterial efficacy of Althaea officinalis, Ziziphus jujuba, Cordia latifolia and Thymus vulgaris out of a total 21 plants against wide range of bacteria including MRSA. This study was therefore, designed to confirm efficacy of these four herbs against MRSA in an animal model.

Methods: A pilot study was conducted to establish the dose of S. aureus (KY698020) required to induce clinical infection. Afterword, in main trial, efficacy of aforementioned plant extracts on the course of sore throat was checked by evaluating general health, gross lesion score, bacterial load and hematology in mice.

Results: Pilot study revealed that $40 \mu$ dose of $10^{7} \mathrm{CFU} / \mathrm{ml}$ could induce infection which persist upto 08 days post infection. Mice treated with T. vulgaris and Z. jujuba showed reduction in gross lesion score of both heart and lungs. Treatment with only some plants could significantly decrease bacterial load of throat (T. vulgaris) heart, blood and joint (C. latifolia, and T. vulagris). Hematological indicators confirmed in vivo control of MRSA infection in all treatment groups except $A$. officinalis.

Conclusion: This is first report confirming in vivo anti-MRSA potential of C. latifolia and T. vulgaris and highlight the need to explore bioactive constituents of these plants. Moreover, previously reported in vitro antibacterial efficiency of $A$. officinalis could not be validated in current study.
\end{abstract}

Keywords: S. aureus, T. vulgaris, Z. jujuba, in vivo, A. officinalis, C. latifolia, Haematology, Bacterial load, Lesion score

\section{Background}

Herbal medicines have gained popularity throughout world as alternative therapeutics for controlling common infections. The emergence of multiple drug resistant strains of bacteria and high cost of synthetic compounds has directed researchers to look for new therapeutic agents including medicinal plants $[1,2]$. Many laboratories are currently involved in documenting application of medicinal plants against infectious and noninfectious diseases through in vitro and in vivo systems $[3,4]$. Previously we have described in vitro anti-MRSA potential of 29 herbs, of which Althaea officinalis, Ziziphus jujuba, Cordia latifolia and Thymus vulgaris were found superior in controlling MRSA [5].

Ethanol and water extracts of $A$. officinalis flower, its flavonoid hypolaetin 8-glucoside have already been reported to have antibacterial, antifungal, anti-inflammatory, analgesic, anti-ulcer and antiviral activity [6-8]. Z. jujuba is

\footnotetext{
* Correspondence: najmaarshad@gmail.com; najmaarshad.zool@pu.edu.pk 'Department of Zoology, University of the Punjab, Lahore, Punjab, Pakistan Full list of author information is available at the end of the article
}

reported to be rich in flavonoids, saponins, tannins, vitamin $\mathrm{A}$ and $\mathrm{B}$, carbohydrates, calcium, phosphate and iron and has been found effective against multiple ailments [9-15]. C. latifolia has also been documented to possess antimicrobial, antibiotic-modifying, anti-inflammatory, antinociceptive, antifertility, toxicity, anti-snake bite, hypolipidemic, immunomodulatory, insecticidal and antioxidant [16-21]. Similarly, therapeutic properties of T. vulgaris have been reported by various authors [22-29]. However, previous claims on antimicrobial efficacy of these herbs are solely based on in vitro experimentation which sometimes yield misleading results therefore, verification of efficacy in vivo is considered crucial. This part of study was focused on in vivo validation of the anti-MRSA potential of C. latifolia, A. officinalis, T. vulgaris and Z. jujuba.

\section{Methods}

\section{Bacteria and culture conditions}

The S. aureus strain KY698020 was isolated from sore throat patients and used in this study. It was characterized 
on the basis of its anti-biogram and molecular properties. The challenge strain contained $c l f A, s p a, C P s 8$, tst, sea, sed genes and was resistant to methicillin, cefixime, oxacillin, gentamycin and penicillin. The pure culture was kept at $-80{ }^{\circ} \mathrm{C}$ and refreshed on Mannitol salt agar plate (Oxoid) before use.

\section{Inoculum preparation}

The test strain was refreshed on Lauria Britanica broth at $37{ }^{\circ} \mathrm{C}$ for $24 \mathrm{~h}$. For inoculum preparation, culture was centrifuged at $3380 \times \mathrm{g}$ for $15 \mathrm{~min}$ and pellet was washed twice with PBS. The optical density was adjusted at $1 \pm$ 0.02 (at $600 \mathrm{~nm}$ ) analogous to app. $10^{11} \mathrm{CFU} / \mathrm{ml}$ and tenfold dilutions of this suspension was used in mice to establish infection model [30]. The corresponding CFU/ $\mathrm{ml}$ was confirmed by plating $100 \mu \mathrm{l}$ of serial dilution of the inoculum on Mannitol salt agar plates.

\section{Plant extract preparation}

Plant extracts were prepared in 99.99\% methanol (10 g/ $100 \mathrm{ml}$ ). Extraction was accomplished in a sonicator for $2 \mathrm{~h}$ at room temperature. The resulting extracts were filtered, concentrated in a rotary evaporator, dried and stored at $4{ }^{\circ} \mathrm{C}$ until further use. These extracts were administered to mice (Mus musculus) by force feeding at the rate of $200 \mathrm{mg} / \mathrm{ml}$ per $\mathrm{kg}$ of body weight.

\section{Ethical statement}

All animals were used in study according to the rulings of the Institute of Laboratory Animal Resources, Commission on Life Sciences, National Research Council (UK). The protocol used was reviewed and approved by the Animal Experiment Administration Committee of University of the Punjab, Lahore, Pakistan.

\section{Animals and housing conditions}

A total of $100 \mathrm{~S}$. aureus free mice (Mus musculus) were used in this study and maintained in animal house, Department of Zoology. The mice were distributed randomly in isolated metallic cages of size $\left(144^{\prime \prime} \times 10^{\prime \prime} \times 7{ }^{\prime \prime}\right)$ under controlled conditions at $30{ }^{\circ} \mathrm{C}$ with 12 -h variation of light and dark period. Water and feed were provided ad libitum. Adults mice (25-30 g weight, both genders) were acclimatized for 1 week prior to the experiment. Three randomly selected mice were sacrificed and screened for the presence of $S$. aureus in throat, lungs, heart, joints and blood by impression technique on selective medium (Mannitol salt agar supplemented with $2.08 \mu \mathrm{g} / \mathrm{ml}$ of vancomycin).

\section{Experiment 2 (main study)}

Animals and grouping

In main study, 42 animals were divided in seven groups (I - VII). To check out the specific objectives, group I and II were kept as negative and positive control respectively, group III received treatment with known antibiotic and group IV - VII served as experimental group and received the calculated dose of methanolic extract of selected plant.

\section{Infection and treatment}

Animals in the group IV- VII were treated with A. officinalis, C. latifolia, T. vulgaris and $Z$. jujuba with dose of $200 \mathrm{mg} / \mathrm{ml}$ per $\mathrm{kg}$ of body weight respectively. Infection was given to group II - VII with $40 \mu \mathrm{l}$ of $4 \times 10^{7} \mathrm{CFU} / \mathrm{ml}$ through intra-tracheal route. Antibiotic and plant extracts were administered by force feeding through feeding needle once daily. Animals were observed for visible signs, symptoms and mortality on daily basis for a period of 7 days.

\section{Sampling}

On eighth day post infection, all animals were euthanized by intra peritoneal injection of ketamine $(200 \mathrm{mg} /$ $\mathrm{kg}$ of body weight) and their blood samples were stored at $4{ }^{\circ} \mathrm{C}$ in EDTA vials. Throat, lung, heart, blood and joints were separated aseptically for bacteriological load examination and blood samples were assessed for hematological studies.

\section{Scoring scheme and laboratory procedures Gross pathological lesion score}

Tissue lesions on lung and heart were noticed and scored as follows: Heart: $0=$ normal; $1=$ vascularization (ii) Lung: $0=$ normal; $1=$ edema, hyperemia and fibrin in air sacs; $2=$ small blood patches; $3=$ large blood patches.

\section{Bacteriological examinations in tissues Qualitative examination (re-isolation of test strain from tissue)}

The presence of test strain in throat, lung, heart, blood and joint were determined qualitatively by streaking the samples directly on selected media. The plates were incubated at $37^{\circ} \mathrm{C}$ for $24 \mathrm{~h}$ and checked for the presence of S. aureus.

\section{Quantitative examination (bacterial load determination)}

Weighed portion of throat, lung, heart, joint and blood was homogenized in 1-2 mL of PBS. About $50 \mu \mathrm{l}$ of serial dilutions of the mixture were spread on Mannitol salt agar plates to check for bacterial quantification. Data was expressed as CFU/g of issue and CFU/ml of blood.

\section{Hematology and clinical biochemistry of blood samples} Hematological examination of blood including hemoglobin $(\mathrm{Hb})$, red blood cell count (RBC), packed cell volume (PCV), total leucocyte count (TLC) was done through auto-analyzer. Erythrocytes sedimentation rate (ESR) 
and differential leukocyte count (DLC) were performed manually.

\section{Data analysis}

The data were analyzed using one-way ANOVA followed by Duncan's multiple range tests. All analyses were performed in SPSS software for window version 16.0 (SPSS). Probability values $\leq 0.05$ were considered significant.

\section{Results}

Experiment 1 (pilot study)

\section{Establishing an infection model}

Mice inoculated with $40 \mu \mathrm{l}$ of $2 \times 10^{6} \mathrm{CFU} / \mathrm{ml} \mathrm{S}$. aureus remained clinically healthy upto 6 days post infection. Bacteria could not be isolated from throat, liver, lungs, heart, blood and joint after 3 days post infection (dpi) onward. No significant variation in body weight could be observed in the treated and controlled group. No gross lesion in lungs and heart could be observed in autopsy and similarly bacteria could not be isolated from any organ. The mice inoculated with $40 \mu \mathrm{l}$ of $4 \times 10^{7} \mathrm{CFU} /$ $\mathrm{ml}$ showed signs of pathological condition with watery nose, lethargic condition and high body temperature. On day seven post infection gross lesions were observed in the lungs of all animals and re-isolation of the $S$. aureus was also recorded from the throat, lungs, heart, joint and blood. In addition, only 1 animal died during the experimental time. The loss in body weight of the mice was also noticed at the end of the experiment. When animals were inoculated with a higher dose of $40 \mu \mathrm{l}$ of $5 \times$ $10^{8} \mathrm{CFU} / \mathrm{ml}$, all animals showed adverse clinical signs characterized by apathy, lethargy, high body temperature, loss of body weight, ruffled coat and around 50\% mice were dead by 4 th dpi. The surviving mice were weak and sacrificed at 8th dpi. During necropsy, the gross lesions were observed in lungs (edema and hyperemia), and heart (vascularization). Test strain could be re-isolated from all tissues studied (throat, lungs, heart, blood and joint). All three doses effected the blood parameters including ESR, $\mathrm{Hb}, \mathrm{RBC}$, platelet, PCV, TLC, neutrophils, lymphocytes, monocytes and eosinophil (Tables 1 and 2).

\section{Part II (main study)}

The dose $40 \mu \mathrm{l}$ of $4 \times 10^{7} \mathrm{CFU} / \mathrm{ml}$ at which less mortality and re-isolation from all the organs were noticed was selected for main study. Another parameter, "the bacterial load", was also added in the main experiment.

The effect of treatment with plants extract in mice is presented in Table 3. Body weight of the animals at the end of the experiment was significantly less in infection control group/positive control group, however, in the treated groups there was no difference in the final body weight of the animals. In positive control group mortality was $16 \%(n=1 / 6)$ in contrast to $0 \%$ in all treated
Table 1 Pilot study: Effects of different doses of S. aureus (KY698020) on survival and re-isolation frequency in mice

\begin{tabular}{llll}
\hline Parameters & Doses (CFU/ml) & & \\
\cline { 2 - 4 } & $5 \times 10^{8}$ & $4 \times 10^{7}$ & $2 \times 10^{6}$ \\
\hline Mortality & $13 / 25$ & $4 / 25$ & $0 / 25$ \\
Re-isolation at day 7 post infection & & \\
Throat & $12 / 12$ & $21 / 21$ & $1 / 25$ \\
Lungs & $12 / 12$ & $21 / 21$ & $0 / 25$ \\
Heart & $12 / 12$ & $20 / 21$ & $0 / 25$ \\
Joint & $12 / 12$ & $20 / 21$ & $0 / 25$ \\
Blood & $12 / 12$ & $20 / 21$ & $0 / 25$ \\
\hline
\end{tabular}

except $A$. officinalis where $50 \%$ mortality rate was noted at $5 \mathrm{dpi}$. Inoculated strain could only be isolated from heart of $A$. officinalis and blood of $Z$. jujuba and A. officinalis treated animals.

\section{Gross pathological lesion scoring}

The gross lesion score of heart and lung in animals receiving $A$. officinalis was significantly higher $(P<0.05)$ in comparison with animals treated with C. latifolia, $T$. vulgaris and $Z$. jujuba, in contrast the lesion score of $C$. latifolia, T. vulgaris and Z. jujuba treated animals was similar to that of negative control (Table 4).

\section{Bacterial load estimation}

Only T. vulgaris treatment resulted in a significant reduction in bacterial load of throat. Likewise, in heart, joint and blood a significant reduction in bacterial load of was observed in $Z$. jujuba and A. officinalis treated animals, while from $C$. latifolia and $T$. vulgaris treated animals, the test strain was not recovered (Table 5).

Table 2 Effect of different doses of S. aureus on hematological prameters of Mice

\begin{tabular}{llll}
\hline Blood parameter & \multicolumn{3}{l}{ Dose $(\mathrm{CFU} / \mathrm{ml})$} \\
\cline { 2 - 4 } & $5 \times 10^{8}$ & $4 \times 10^{7}$ & $2 \times 10^{6}$ \\
\hline ESR $(\mathrm{mm} / \mathrm{h})$ & $31.00 \pm 0.57^{\mathrm{a}}$ & $27.80 \pm 2.35^{\mathrm{a}}$ & $2.33 \pm 0.66^{\mathrm{b}}$ \\
$\mathrm{Hb}(\mathrm{g} / \mathrm{dl})$ & $7.20 \pm 0.60^{\mathrm{c}}$ & $9.56 \pm 0.54^{\mathrm{b}}$ & $15.33 \pm 0.33^{\mathrm{a}}$ \\
$\mathrm{RBC} / \mathrm{mm} 3$ & $2.26 \pm 0.21^{\mathrm{a}}$ & $4.17 \pm 0.66^{\mathrm{b}}$ & $5.36 \pm 0.166 \mathrm{~b}$ \\
Platelet ${ }^{*} 1000$ & $379.67 \pm 11.1$ & $492.60 \pm 1.35$ & $333.33 \pm 16.66$ \\
PCV (\%) & $25.66 \pm 2.18^{\mathrm{a}}$ & $35.46 \pm 2.95^{\mathrm{b}}$ & $42.46 \pm 0.73^{\mathrm{b}}$ \\
TLC $^{*} 1000$ & $9.33 \pm 0.66$ & $5.16 \pm 2.26$ & $1.97 \pm 1.93$ \\
Neutrophil (\%) & $34.33 \pm 4.70^{\mathrm{a}}$ & $26.00 \pm 4.58^{\mathrm{ab}}$ & $11.67 \pm 1.66^{\mathrm{b}}$ \\
Lymphocyte (\%) & $66.66 \pm 3.33$ & $70.20 \pm 5.4$ & $61.67 \pm 3.33$ \\
Monocyte (\%) & $2.00 \pm 0.00$ & $2.00 \pm 0.00$ & $1.00 \pm 0.00$ \\
Eosinophil (\%) & $2.67 \pm 0.33^{\mathrm{a}}$ & $2.40 \pm 0.24^{\mathrm{a}}$ & $0.67 \pm 0.33^{\mathrm{b}}$ \\
\hline
\end{tabular}

Data was analysed using One way ANOVA followed by Tukey's test. The values (in rows) having different letter, in superscript, are significantly different at $p \leq 0.05$ 
Table 3 Main study: Effects of plant extract treatment on clinical outcome of infected animals at 8 days post infection

\begin{tabular}{|c|c|c|c|c|c|c|c|}
\hline \multirow[t]{2}{*}{ Parameters } & \multicolumn{7}{|l|}{ Groups } \\
\hline & Positive control & Negative control & Antibiotic & A. officinalis & C. latifolia & T. vulgaris & Z. jujuba \\
\hline Mortality & $1 / 6$ & $0 / 6$ & $0 / 6$ & $3 / 6$ & $0 / 6$ & $0 / 6$ & $0 / 6$ \\
\hline Body weight & $23.36 \pm 0.620$ & $26.83 \pm 0.29$ & $25.18 \pm 1.05$ & $25.93 \pm 0.95$ & $24.65 \pm 0.78$ & $25.96 \pm 0.85$ & $25.92 \pm 1.20$ \\
\hline \multicolumn{8}{|c|}{ Re-isolation at day 8 post infection } \\
\hline Throat & $6 / 6$ & $0 / 6$ & $3 / 6$ & $3 / 3$ & $6 / 6$ & $6 / 6$ & $6 / 6$ \\
\hline Lung & $6 / 6$ & $0 / 6$ & $3 / 6$ & $3 / 3$ & $6 / 6$ & $5 / 6$ & $6 / 6$ \\
\hline Heart & $6 / 6$ & $0 / 6$ & $0 / 6$ & $3 / 3$ & $0 / 6$ & $0 / 6$ & $0 / 6$ \\
\hline Joint & $6 / 6$ & $0 / 6$ & $0 / 6$ & $0 / 3$ & $0 / 6$ & $0 / 6$ & $0 / 6$ \\
\hline Blood & $6 / 6$ & $0 / 6$ & $0 / 6$ & $3 / 3$ & $0 / 6$ & $0 / 6$ & $5 / 6$ \\
\hline
\end{tabular}

\section{Haematological assessment}

Infection resulted both in reduction of $\mathrm{Hb}, \mathrm{RBC}, \mathrm{PCV}$, platelet count and elevation in ESR. While treatment with $C$. latifolia, $T$. vulgaris and $Z$. jujuba indicated therapeutic efficacy by inhibiting changes in aforementioned parameters. T. vulgaris treated group showed significant elevation in RBC count which was even more than negative control (Table 6).

Similar trend was observed while comparing total and differential leukocyte count of group I-VII. Total leucocyte, neutrophil, lymphocytes and eosinophil counts of mice treated with C. latifolia, T. vulgaris and Z. jujuba were significantly better than positive control group but A. officinalis treatment did not yield admirable results. Infection did not alter monocyte count (Table 6).

\section{Discussion}

In vivo studies are crucial for supporting in vitro findings. The current study describes in vivo anti-MRSA efficacy of four methanolic plants extracts which are normally used in herbal remedies to control sore throat. Establishing the infection model is the basic requirement of such studies. The dose of bacteria to establish infection depends on the type and virulence of strain, host species, quantity of pathogen and site of inoculation. Therefore, a pilot study was conducted to check pathogenicity and infectious dose of a clinical strain of MRSA in mice.
The experiment revealed that $40 \mu \mathrm{l}$ dose of $10^{7} \mathrm{CFU} /$ $\mathrm{ml}$ was sufficient to induce infection and this infection persisted up to $08 \mathrm{dpi}$ in a murine model. Therefore, this dose was decided for the main experiment. Fu et al. [30] and Cho et al. [31] succeeded in inducing S. aureus infection by injection $4 \times 10^{7}$ and $2 \times 10^{6} \mathrm{CFU} / \mathrm{ml}$ in mice. Arshad et al. [32] established model of collibacillosis by injecting $4.3 \log _{10} \mathrm{CFU} / \mathrm{ml}$ through intraperitoneal route.

In main study, ameliorating effects of C. latifolia, $A$. officinalis, T. vulgaris and Z. jujuba were studied. Animals treated with $T$. vulgaris and $Z$. jujuba showed reduction in gross lesion score of both heart and lungs while $C$. latifolia treatment reduced gross lesion in lungs only. Gross lesion develops in tissues due to bacterial virulence. MRSA release toxins which lead to hemolysis in $\mathrm{RBC}$, its adhesion in walls of tissue and resistance to phagocytosis [33]. Reduction in gross lesion score of lungs points towards some role of these extracts in controlling MRSA infection in in vivo system.

$S$. aureus circulates in blood, later on it adheres to components of the extracellular matrix, forming thrombus, or endothelial cells of the host and initiate colonization [34]. It can also interact with vascular endothelial cells [35], extracellular matrix [36] and platelets $[37,38]$. Several surface proteins of $S$. aureus have high specificity to matrix and plasma proteins and have been shown to mediate these adhesion processes [39]. S.

Table 4 Comparison of Gross lesion scores in lungs and heart following treatment of infection with different plant extracts

\begin{tabular}{|c|c|c|c|c|c|c|}
\hline Groups & Positive control & Antibiotic & Negative control & A. officinalis & C. latifolia & T. vulgaris \\
\hline Antibiotic & $0.034,0.43$ & & & & & \\
\hline Negative control & $0.034,0.034$ & $1.00,0.317$ & & & & \\
\hline A. officinalis & $0.581,0.197$ & $0.086,0.068$ & $0.086,0.034$ & & & \\
\hline C. latifolia & $0.05,0.014$ & $1.00,1.00$ & $1.00,0.285$ & $0.022,0.027$ & & \\
\hline T. vulgaris & $0.005,0.005$ & $1.00,0.157$ & $1.00,1.00$ & $0.022,0.005$ & $1.00,0.138$ & \\
\hline Z. jujuba & $0.005,0.016$ & $1.00,0.655$ & $1.00,0.157$ & $0.022,0.038$ & $1.00,0.575$ & $1.00,0.056$ \\
\hline
\end{tabular}

Gross lession score was compared using Kruskle-Wallis test. Comparison among groups was performed using Mann Whitney $U$ test. $P \leq 0.05$ was considered significant. Data is presented in terms of $P$-values of lungs and hearts respectively 
Table 5 Effect of treatment with selected medicinal plants on bacterial load of different tissues

\begin{tabular}{|c|c|c|c|c|c|}
\hline \multirow[t]{2}{*}{ Groups } & \multicolumn{5}{|l|}{ Organs } \\
\hline & Throat & Lungs & Heart & Joints & Blood \\
\hline Positive control & $4.88 \pm 0.20^{a}$ & $5.36 \pm 0.58^{\mathrm{a}}$ & $4.52 \pm 0.09^{a}$ & $3.89 \pm 0.23^{\mathrm{a}}$ & $4.11 \pm 0.11^{\mathrm{a}}$ \\
\hline Vancomycin & $2.50 \pm 1.02^{c}$ & $2.50 \pm 1.02^{c}$ & $0.00 \pm 0.00^{c}$ & $0.00 \pm 0.00^{c}$ & $0.00 \pm 0.00^{c}$ \\
\hline A. officinalis & $4.60 \pm 0.13^{a b}$ & $4.60 \pm 0.13^{\mathrm{ab}}$ & $3.31 \pm 0.43^{c}$ & $3.36 \pm 0.23^{\mathrm{a}}$ & $3.94 \pm 0.59^{b}$ \\
\hline C. latifolia & $4.45 \pm 0.20^{\mathrm{ab}}$ & $4.45 \pm 0.20^{\mathrm{ab}}$ & $0.00 \pm 0.00^{d}$ & $0.00 \pm 0.00^{c}$ & $0.00 \pm 0.00^{c}$ \\
\hline T. vulgaris & $2.93 \pm 0.60^{b c}$ & $3.83 \pm 0.11^{\mathrm{abc}}$ & $0.00 \pm 0.00^{d}$ & $0.00 \pm 0.00^{c}$ & $0.00 \pm 0.00^{c}$ \\
\hline Z. jujuba & $4.44 \pm 0.13^{\mathrm{ab}}$ & $4.44^{\mathrm{ab}} \pm 0.13$ & $3.77 \pm 0.13^{b}$ & $1.20 \pm 0.76^{b}$ & $3.42^{b} \pm 0.15^{b}$ \\
\hline
\end{tabular}

Data was analysed using One way ANOVA followed by Tukey's test. The values (in columns) having no common letter, in superscript, are significantly different at $p \leq 0.05$. Bacterial load is represented as Mean \pm SE of CFU $\left(\log _{10}\right) / g$ of tissue or CFU $\left(\log _{10}\right) / \mathrm{ml}$ of the blood

aureus is also known to bind to red blood cells (RBCs) in the presence of plasma proteins such as fibrinogen [40, 41]. Re-isolation and bacterial load from throat, lungs, heart, blood and joint was performed as an indicator of adhesion and persistency of $S$. aureus in tissues. Our data revealed a significant reduction in bacterial load of (a) throat in T. vulgaris treated group (b) lungs in antibiotic treated group (c) heart and blood of all treated groups except Z. jujuba and A. officinalis and (d) joint in Z. jujuba and $A$. officinalis. The reduction in bacterial load may be due to bactericidal/bacteriostatic effects of phytochemicals such as alkaloids, flavonoids and phenolic compound present in crude extracts [42]. Our findings are in accordance with Owais et al. [43], who reported a reduction in bacterial load in vital organs of mice after treatment with Withania somnifera L. Dunal.

Hematological studies provide a good indication of the progress of bacterial infection as well as treatment. Elevated level of ESR, TLC, neutrophils and lymphocyte count are reliable indicators of infection in the body and they dropped to normal range after effective treatment [44]. S. aureus was known to contain hemolysin that can help in targeted killing of host cells. A reduction in $\mathrm{Hb}$,
$\mathrm{RBC}$, platelet and PCV was noticed in untreated infected group under study. It may either be due to lysis of RBC during infection or depletion of iron in body indirectly inhibiting erythropoiesis. There are evidences that $S$. aureus is capable of using hemoglobin as a sole iron for growth $[45,46]$. Among treated group, except for $A$. officinalis, all plants displayed improvement in haemalogical parametrs. Best adjustment of ESR and lymphocytes was observed after treatment with C. latifolia, $T$. vulgaris and $Z$. jujube, in addition, C. latifolia and T. vulgaris groups had platelet and neutrophil count similar to negative control showing their higher potency in controlling infection. Sur and Ganguly [47] reported a reversal in haematological parameters following treatment with tea plant root extract in Ehrlich ascites carcinoma induced mice. Several studies have reported the antibacterial activity of A. officinalis through in vitro procedures $[6-8,45]$, but its efficiency in in vivo system could not be validated, highlighting the importance of in vivo studies.

\section{Conclusion}

To the best of our knowledge, this is the first report investigating in vivo antimicrobial efficacy of $A$. officinalis,

Table 6 Effect of medicinal plant treatment on hematological parameters of mice at 8th -day post infection

\begin{tabular}{|c|c|c|c|c|c|c|c|}
\hline \multirow[t]{2}{*}{ Blood parameter } & \multicolumn{7}{|l|}{ Groups } \\
\hline & Positive control & Negative control & Vancomycin & A. officinalis & C. latifolia & T. vulgaris & Z. jujuba \\
\hline ESR mm/h & $32.00 \pm 1.73^{a}$ & $3.67 \pm 0.33^{e}$ & $6.50 \pm 0.33^{d}$ & $24.00 \pm 0.57^{b}$ & $12.33 \pm 1.17^{c}$ & $13.83 \pm 0.47^{c}$ & $14.50 \pm 0.6^{c}$ \\
\hline $\mathrm{Hb} \mathrm{g} / \mathrm{dL}$ & $10.10 \pm 1.25^{b}$ & $14.67 \pm 0.33^{a}$ & $14.33 \pm 0.33^{a}$ & $10.67 \pm 0.66^{b}$ & $14.67 \pm 0.33^{a}$ & $13.94 \pm 0.49^{a}$ & $14.00 \pm 0.025^{a}$ \\
\hline $\mathrm{RBC} / \mathrm{mm} 3$ & $6.19 \pm 0.80^{d}$ & $8.79 \pm 0.30^{a b}$ & $7.34 \pm 0.33^{c}$ & $8.00 \pm 0.33 b^{c}$ & $8.17 \pm 0.16^{b c}$ & $9.33 \pm 0.42^{a}$ & $8.33 \pm 0.33 b c$ \\
\hline Platelets*1000 & $129.33 \pm 3.48^{e}$ & $385 \pm 7.63^{a}$ & $380.00 \pm 22.91^{a}$ & $211.67 \pm 21.66^{d}$ & $385.00 \pm 3.41^{a}$ & $367.50 \pm 8.34^{a}$ & $314.17 \pm 12.80^{b}$ \\
\hline PCV \% & $33.53 \pm 4.61^{b}$ & $41 \pm 0.00^{a}$ & $40.00 \pm 0.00^{a}$ & $40.00 \pm 0.00^{a}$ & $40.17 \pm 0.16 a$ & $39.00 \pm 0.00^{a}$ & $40.33 \pm 0.21^{a}$ \\
\hline TLC *1000 & $9.0 \pm 230.00^{a}$ & $5.63 \pm 18.62^{b}$ & $6.10 \pm 20.81^{b}$ & $7.13 \pm 18.55^{b}$ & $6.13 \pm 4.94^{b}$ & $6.10 \pm 7.60^{b}$ & $6.25 \pm 13.60^{b}$ \\
\hline Neutrophil (\%) & $21.00 \pm 2.08^{a}$ & $10.67 \pm 0.42^{d}$ & $12.33 \pm 1.45^{\mathrm{cd}}$ & $19.00 \pm 3.78^{a b}$ & $13.33 \pm 1.66^{\mathrm{cd}}$ & $12.50 \pm 0.34^{\mathrm{cd}}$ & $16.33 \pm 1.28^{b c}$ \\
\hline Lymphocyte (\%) & $86.33 \pm 5.20^{a}$ & $71.17 \pm 2.55 c$ & $72.22 \pm 1.20 c$ & $81.67 \pm 4.41^{a b}$ & $82.83 \pm 0.91^{\mathrm{ab}}$ & $83.33 \pm 1.66^{a b}$ & $80.00 \pm 1.26^{b}$ \\
\hline Monocyte (\%) & $2.00 b \pm 0.00$ & $1.33 \pm 0.33$ & $1.33 \pm 0.33$ & $4.67 \pm 0.33$ & $1.00 \pm 0.00$ & $2.00 \pm 0.00$ & $1.17 \pm 0.16$ \\
\hline Eosinophil (\%) & $2.33 b \pm 0.33^{b}$ & $1.2 b \pm 0.2^{b}$ & $1.33 \pm 0.33^{c}$ & $3.33 \pm 0.33^{a}$ & $1.00 \pm 0.00^{c}$ & $1.00 \pm 0.00^{c}$ & $1.17 \pm 0.167^{c}$ \\
\hline
\end{tabular}

Data was analysed using One way ANOVA followed by Tukey's test. The values (in columns) having no common letter, in superscript, are significantly different at $p \leq 0.05$. Data are presented in term of Mean \pm SE 
Z. jujuba, C. latifolia and T. vulgaris. However, there is no denial to seek for active constituents, their serumattainable levels, pharmacokinetic properties and diffusion. Current study offered a scientific basis for the medicinal application for C. latifolia and T. vulgaris extracts against MRSA-associated infections. The antimicrobial activities could be enhanced if their active components are purified and adequate dosage determined for proper administration. This may go a long way in curbing administration of inappropriate concentration; a common practice among many traditional medical practitioners. Secondly, inefficiency of A. officinalis in controlling MRSA induced infections emphasizes on employment of in vivo systems for determining therapeutic efficacy of medicinal plants.

\section{Abbreviations}

ANOVA: Analysis of variance; app.: Approximately; CFU: Colony forming units; DLC: Differential leukocyte count; dpi: Days post infection; EDTA: Ethylene diamine tetra acetic acid; ESR: Erythrocytes sedimentation rate; Hb: Hemoglobin; MRSA: Methicillin resistant Staphylococcus aureus; PBS: Phosphate buffer saline; PCV: Packed cell volume; RBC: Red blood cell count; SPSS: Statistical program for social sciences; TLC: Total leucocyte count

\section{Funding}

Current study was funded by Higher Education Commission, Pakistan, Grant No. 106-1813-BM6-143 for Indigenous PhD Fellowship Program.

\section{Availability of data and materials}

All data generated or analyzed during this study are included in this published article.

\section{Authors' contributions}

Participated in research design: NA, AM, IL, MA, HA. Conducted experiments: NA, AM, IL. Performed data collection: NA, AM, MA. Performed data analysis: NA, MA, HA. Wrote the manuscript: NA, AM, IL. All authors read and approved the final manuscript.

\section{Ethics approval}

All experiments on animals were performed in compliance with the rulings of the Institute of Laboratory Animal Resources, Commission on Life Sciences, National Research Council (UK). The Institutional Animal Care and Use Committee of University of the Punjab, Lahore, Pakistan approved research following mice protocols.

\section{Consent for publication}

Not applicable.

\section{Competing interests}

The authors declare that they have no competing interests.

\section{Publisher's Note}

Springer Nature remains neutral with regard to jurisdictional claims in published maps and institutional affiliations.

\section{Author details}

'Department of Zoology, University of the Punjab, Lahore, Punjab, Pakistan. 2Department of Zoology, Government College University, Lahore, Punjab, Pakistan. ${ }^{3}$ Department of Zoology, University of Education, Lahore, Punjab, Pakistan. ${ }^{4}$ Department of Botany, University of the Punjab, Lahore, Punjab, Pakistan.
Received: 17 May 2017 Accepted: 13 November 2017

Published online: 23 November 2017

\section{References}

1. De Albuquerque UP. Re-examining hypotheses concerning the use and knowledge of medicinal plants: a study in the Caatinga vegetation of NE Brazil. J Ethnobiol Ethnomed. 2006:2:1-10.

2. Prihanto AA, Firdaus M, Nurdiani R. Anti-Methicillin resistant Staphylococcus aureus (MRSA) of methanol extract of mangrove plants leaf: preliminary report. Drug Invent Today. 2012;4:439-40.

3. Gibbons S. Anti-staphylococcal plant natural products. Nat Prod Rep. 2004. 21:263-77.

4. Simoes M, Bennett RN, Rosa EA. Understanding antimicrobial activities of phytochemicals against multidrug resistant bacteria and biofilms. Nat Prod Rep. 2009;26:746-57.

5. Mehreen A, Waheed M, Liaqat I, Arshad N. Phytochemical, antimicrobial, and toxicological evaluation of traditional herbs used to treat sore throat. Biomed Res Int. 2016;2016:8503426. 9 pages

6. Zarei B, Saifi T, Fazeli A, Khodadadi E, Namavar A. Evaluation of antibacterial effects of marshmallow (Althaea officinalis) on four strains of bacteria. IJACS. 2013;5:1571

7. Rezaei M, Dadgar Z, Noori-Zadeh A, Mesbah-Namin SA, Pakzad I, Davodian E. Evaluation of the antibacterial activity of the Althaea officinalis L. leaf extract and its wound healing potency in the rat model of excision wound creation. Avicenna J Phytomed. 2015;5:105-12.

8. May G, Willuhn G. Antiviral activity of aqueous extracts from medicinal plants in tissue cultures. Arzneimittelforschung. 1978;28:1-7.

9. Kim DS, Pezzuto JM, Pisha E. Synthesis of betulinic acid derivatives with activity against human melanoma. Bioorg Med Chem Lett. 1998;8:1707-12.

10. Ganachari M, Kumar S. Anti-ulcer properties of Ziziphus jujuba lam leaves extract in rats. J Nat Remed. 2004:4:103-8.

11. Kumar S, Ganachari M, Nagoor V. Anti-inflammatory activity of Ziziphus jujuba lam leaves extract in rats. J Nat Remed. 2004;4:183-5.

12. Kim H, Han S. Zizyphus jujuba and Codonopsis Pilosula stimulate nitric oxide release in cultured endothelial cells and kidney tissues. Asia Pacific J Pharma. 1996;11:121-8.

13. Fukuyama Y, Mizuta K, Nakagawa K, Wenjuan Q, Xiue W. A new neo-Lignan, a prostaglandin 12 inducer from the leaves of Zizyphus jujuba. Planta Med. 1986:52:501-2.

14. Esteki T, Urooj A. Antioxidant components and activity in the peel of Ziziphus Jujuba mill. J Pharm Res. 2012:5:2705-9.

15. Sarfaraz A, Ansari SH, Porchezhian E. Antifungal activity of alcoholic extracts of Ziziphus vulgaris and Acacia concinna. Hamdard Medicus. Bait al-Hikmah, Karachi., 2002. 14/15, 42-45.

16. Al-Musayeib N, Perveen S, Fatima I, Nasir M, Hussain A. Antioxidant, antiglycation and anti-inflammatory activities of phenolic constituents from Cordia sinensis. Molecules. 2011;16:10214-26.

17. Salazar-Aranda R, Pérez-López LA, López-Arroyo J, Alanís-Garza BA, Waksman de Torres N. Antimicrobial and antioxidant activities of plants from northeast of Mexico. Evid Based Complement Alternat Med. 2011; doi: 10. 1093/ecam/nep127.

18. Paulino RDC, Henriques GPDSA, Neto HDSL, Coelho MDFBD, JLD L. Influência do substrato na propagac, ão por estaquia de Cordia globosa. Revista Verde. 2011;6:274-8.

19. Sharma VK, Asati DP. Pediatric contact dermatitis. Ind J Dermatol Venereo Leprol. 2010;76:514-20.

20. Bhattacharya P, Saha A. Evaluation of reversible contraceptive potential of Cordia dichotoma leaves extract. Rev Bras Farmacogn. 2013;23:342-50.

21. Nariya PB, Bhalodia NR, Shukla V, Acharya R. Antimicrobial and antifungal activities of Cordia Dichotoma (Forster F.) bark extracts. Ayu. 2011;32:585-9.

22. Marino M, Bersani C, Comi G. Antimicrobial activity of the essential oils of Thymus vulgaris L. measured using a bioimpedometric method. J Food Prot. 1999;62:1017-23.

23. Höferl M, Buchbauer G, Jirovetz L, Schmidt E, Stoyanova A, Denkova Z, Slavchev A, Geissler M. Correlation of antimicrobial activities of various essential oils and their main aromatic volatile constituents. J Essent Oil Res. 2009;21:459-63.

24. Nolkemper S, Reichling J, Stintzing FC, Carle R, Schnitzler P. Antiviral effect of aqueous extracts from species of the Lamiaceae Family against herpes simplex virus type 1 and type 2 in vitro. Planta Med. 2006;72:1378-82. 
25. Swayeh NH, Abu-Raghif AR, Qasim BJ, Sahib HB. The protective effects of Thymus Vulgaris aqueous extract against Methotrexate-induced hepatic toxicity in rabbits. Int J Pharm Sci Rev Res. 2014;29:187-93.

26. Mohsin A, Shah A, Al-Yahya M, Tariq M, Tanira M, Ageel A. Analgesic, antipyretic activity and phtochemical screening of some plants used in traditional Arab system of medicine. Fitoterapia. 1989;60:174-7.

27. Ozkol H, Tuluce Y, Dilsiz N, Koyuncu I. Therapeutic potential of some plant extracts used in Turkish traditional medicine on streptozocin-induced type 1 diabetes mellitus in rats. J Membr Biol. 2013;246:47-55.

28. Kozics $K$, Klusová $V$, Srančíková A, Mučaji P, Slameňová D, Hunáková L, Kusznierewicz B, Horváthová E. Effects of Salvia officinalis and Thymus vulgaris on oxidant-induced DNA damage and antioxidant status in HepG2 cells. Food Chem. 2013;141:2198-206.

29. Szczepanik M, Zawitowsk B, Szumny A. Insecticidal activities of Thymus vulgaris essential oil and its components (thymol and carvacrol) against larvae of lesser mealworm, Alphitobius diaperinus panzer (Coleoptera: Tenebrionidae). Allelopathy J. 2012;30:129-42.

30. Fu KP, Lafredo SC, Foleno B, Isaacson DM, Barrett JF, Tobia AJ, Rosenthale ME. In vitro and in vivo antibacterial activities of levofloxacin (I-ofloxacin), an optically activeofloxacin. Antimicrob Agents Chemother. 1992;36:860-6.

31. Cho JS, Pietras EM, Garcia NC, Ramos R, Farzam DM, Monroe HR, Magorien JE, Blauvelt A, Kolls JK, Cheung AL, Cheng G, Modlin RL, Miller LS. IL-17 is essential for host defense against cutaneous Staphylococcus aureus infection in mice. J Clin Invest. 2010;120:1762-73.

32. Arshad N, Neubauer $C$, Hasnain S, Hess M. Peganum Harmala can minimize Escherichia coli infection in poultry, but long-term feeding may induce side effects. Poult Sci. 2008:87:240-9.

33. Otto M. Staphylococcus aureus toxins. Curr Opin Microbiol. 2014;17:32-7.

34. Niemann S, Spehr N, Van Aken H, Morgenstern E, Peters G, Herrmann M, Kehrel BE. Soluble fibrin is the main mediator of Staphylococcus aureus adhesion to platelets. Circulation. 2004;1 10:193-200.

35. Peacock SJ, Foster TJ, Cameron BJ, Berendt AR. Bacterial fibronectin-binding proteins and endothelial cell surface fibronectin mediate adherence of Staphylococcus aureus to resting human endothelial cells. Microbiology. 1999;145:3477-86

36. Flock Jl. Extracellular-matrix-binding proteins as targets for the prevention of Staphylococcus aureus infections. Mol Med Today. 1999;5:532-7.

37. Kerrigan SW, Kaw G, Hogan M, Penadés J, Litt D, Fitzgerald DJ, Foster TJ, Cox D. Multiple mechanisms for the activation of human platelet aggregation by Staphylococcus aureus: roles for the clumping factors ClfA and ClfB, the serineaspartate repeat protein SdrE and protein A. Mol Microbiol. 2002;44:1033-44.

38. Sullam PM, Bayer AS, Foss WM, Cheung AL. Diminished platelet binding in vitro by Staphylococcus aureus is associated with reduced virulence in a rabbit model of infective endocarditis. Infect Immun. 1996;64:4915-21.

39. Van Belkum A, Kools-Sijmons M, Verbrugh H. Attachment of Staphylococcus aureus to eukaryotic cells and experimental pitfalls in staphylococcal adherence assays: a critical appraisal. J Microbiol Methods. 2002;48:19-42.

40. Croize J, Gialanella P, Monnet D, Okada J, Orsi A, Voss A, Merlin S. Improved identification of Staphylococcus aureus using a new agglutination test results of an international study. APMIS. 1993;101:487-91.

41. Wilkerson M, Mcallister S, Miller JM, Heiter BJ, Bourbeau PP. Comparison of five agglutination tests for identification of Staphylococcus aureus. J Clin Microbiol. 1997;35:148-51.

42. Benariba N, Djaziri R, Bellakhdar W, Belkacem N, Kadiata M, Malaisse WJ, Sener A. Phytochemical screening and free radical scavenging activity of Citrullus colocynthis seeds extracts. Asian Pac J Trop Biomed. 2013;3(1):35-40. doi:10.1016/S2221-1691(13)60020-9.

43. Owais M, Sharad KS, Shehbaz A, Saleemuddin M. Antibacterial efficacy of Withania somnifera (ashwagandha) an indigenous medicinal plant against experimental murine salmonellosis. Phytomedicine. 2005;12:229-35.

44. Piper KE, Fernandez-Sampedro M, Steckelberg KE, Mandrekar JN, Karau MJ, Steckelberg JM, Berbari EF, Osmon DR, Hanssen AD, Lewallen DG. C-reactive protein, erythrocyte sedimentation rate and orthopedic implant infection. PLoS One. 2010;: 99358.

45. Mazmanian SK, Skaar EP, Gaspar AH, Humayun M, Gornicki P, Jelenska J, Joachmiak A, Missiakas DM, Schneewind O. Passage of heme-iron across the envelope of Staphylococcus aureus. Science. 2003;299:906-9.

46. Pishchany G, Haley KP, Skaar EP. Staphylococcus aureus growth using human hemoglobin as an iron source. J Vis Exp. 2013;72:e50072.

47. Sur P, Ganguly DK. Tea plant root extract (TRE) as an antineoplastic agent. Planta Med. 1994;60:106-9.

\section{Submit your next manuscript to BioMed Central and we will help you at every step:}

- We accept pre-submission inquiries

- Our selector tool helps you to find the most relevant journal

- We provide round the clock customer support

- Convenient online submission

- Thorough peer review

- Inclusion in PubMed and all major indexing services

- Maximum visibility for your research

Submit your manuscript at www.biomedcentral.com/submit 